\title{
The Ethnic Pluralism of the Nineteenth Century in Transylvania according to the Ecclesiastical Painting of the Grecu Brothers
}

\author{
Dragoș BOICU ${ }^{*}$
}

\begin{abstract}
Despite the development of the iconographic programs, the frescoes painted by the Grecu brothers remind us not only of the large ensembles beyond the Carpathians in Walachia and Moldova but also other Transylvanian decorations. These frescoes express not only the spirit of the time or the mentality of the community to which they belonged, but they also represented an opportunity to show the painters' originality and personality, their need for personal affirmation and artistic individuality, connected to a new sensitivity of a given historical context. The representation of the inhabiting nations in Transylvania in the Passion's Cycle highlights the disadvantaged status of the Romanian people who were oppressed by the privileged nations: by the Habsburg military force, the inequitable judgement of Saxons and the torments inflicted by Hungarians through their policies. All of these recreate mutatis mutandis the dramatic setting in which Christ was crucified.
\end{abstract}

Keywords: Transylvania, Church painting, Ecclesiastical art, folk art, Grecu brothers

Amid all the historical regions of Romania, Transylvania has a special history regarding the relations among the inhabiting nations even if it is often stated that it was not cohabitation, but rather colonization. It should be noted that, throughout time, a balance was created among all the ethnicities present in Transylvania even though the relations between them were not necessarily mutually beneficial, the Romanians being excluded from the political life without even fighting back violently. More than that, they assumed the status of a tolerated nation and a tolerated religion. But this balance would be irreparably disrupted at the end of the seventeenth century through the creation of the Greek Catholic Church in Transylvania.

Whether we like to admit it or not, the founding of the Greek Catholic Church represented a milestone in the evolution of this historic region, influencing all populations inhabiting here. Despite its much disputed genesis, Uniatism remains an undeniable reality, viewed in a very different way according to the confessional background of the historians who have classified it either as a socio-cultural emancipation, or as a form of compromise, or even as a betrayal of the ancestral religion, denouncing it as a schism.

* Dragoş Boicu, PhD, Associated Member of the Research Centre for Theology, "Lucian Blaga" University of Sibiu, Romania. Adress. Str. Mitropoliei 20550179 Sibiu, Romania; e-mail: dragosbcu@yahoo.com. 
It is well known that Uniatism is not a new phenomenon in Central and Eastern Europe, such acts being signed by the Synod of Brest-Litovsk in 1596 and after the councils of Ujhorod $(1649,1652)$ and Muncacs $(1690 / 1691)$, but the Orthodox resistance organized itself differently depending on the geographical regions and the historical context. Consequently, the process of synthesizing local values in opposition to the "centralizing" ones of the Habsburg Empire in a given moment helped the shaping, with specific features, of some centrifugal movements that could be undertaken only by their own followers, otherwise producing exclusion, delimitation and disunity. The Romanian Orthodox Church in Transylvania was also in the midst of a process of discovery and affirmation of its identity, highlighted best by using the binomial ethnicity-religion that seemed to separate formally the Romanians from the privileged nations and those nations among each other, being enough to build an identity discourse meant to find the place and the meaning of the Romanians in Transylvania.

Leaving aside the details of the Romanian Orthodox Church separation in Transylvania, it should be noted that the Greek Catholics and the Orthodox have accused a mutual fragmentation of the doctrine involving ultimately a form of religious conscience falsification. This process lead to the diversion of moral principles and transformed them into means of incitement to violence against other Christians who didn't differ from each other at any fundamental doctrinal level, liturgical or disciplinary. Whilst, for the Greek Catholics, the eighteenth century was a period for claiming the rights provided by Leopold's decrees, culminating in the acceptance of young Romanians into the Transylvanian schools, for the Orthodox Romanians it was a constant struggle for survival as a distinct entity facing the emerging danger of Catholicism.

Only the 1781 edict of religious tolerance, issued by Emperor Joseph II, brought them the hope that their condition would eventually change. The law stated that it was permissible for all citizens, of any religion, to build stone churches with bell towers, to raise schools in every village, where there were at least 100 families $^{1}$ living together. Through a new decree, published on 3 September 1783, the emperor stated, with regards to the members of the Greek-Oriental Church, that they were compelled to support, with their own contributions, priests and churches without receiving any "support from the state and other religions" 2 .

\footnotetext{
1 Ioan Lupaş, Istoria bisericească a românilor ardeleni, Sibiu 1918, p. 125, 163.

2 Joseph Heinrich Benigni von Mildenberg, Handbuch der Statistik und Geographie des Großfürstentums Siebenbürgen, vol. II, Sibiu, 1837, p. 50-51 apud: Paul Brusanowski, Pagini din istoria bisericească a Sibiului medieval, Cluj-Napoca 2007, p. 235.
} 
Such a provision of the law raised another obstacle in the way of the Romanians' religious prosperity. They knew that they would not receive any support from the ancient Romanian noble families, denationalized, who had long before abandoned the role they ought to fulfil: the patronage of the religious artworks ${ }^{3}$. The Authorities hindered alike all the support, so generous once, of the princes and boyars from Wallachia and Moldavia. The task of finding the necessary means to build new churches belonged solely to the townsmen and rural communities.

Although they were marginalized and forbidden to enter the professional corporations, among the Romanians there were many craftsmen experienced enough to cope with complex works, such as the masonry of churches and also talented painters with the necessary knowledge of mural techniques and traditional iconography. The most obvious evidence emerges from the large numbers of Orthodox stone churches built in southern Transylvania within three decades between 1780 and $1811^{4}$.

The stylistic unity that characterizes the religious buildings from this period is visible in practicing a planimetric and structural type, which embodies elements of architecture originating south of the Carpathians, vested in Transylvania thanks to the places of worship raised here by the Wallachian princes and boyars, during the 17th century and the beginning of the 18th century. Among the group of churches erected after issuing the edict of tolerance, we recognize such characteristics, more precisely, a rectangular plan of the nave, ending in the eastern part with an unhooked apse, semi-circular inside and polygonal outside, and the system of vaulting of the nave, with a semispherical dome supported by four arches. We add to these features that define the church architecture of this period=the presence of the bell tower, located usually on the west side of the building'.

The existence of a significant number of Transylvanian church painters active in this era was highlighted by the research carried out by many histori-

3 Coriolan Petranu, "L'art roumain de Transylvanie", vol. I, Texte, Extrait de La Transylvanie, Bucureşti 1938, p. 7, 8.

4 Churches from: Săsăuş (1780), Mohu (1782), Făgăraş (1783-1791), Sâmbăta de Jos (1787), Church "Holy Trinity" of Braşov (1787), the church on Strada Lungă of Sibiu (1787), the churches from Ţichindeal (1791), Perşani (1793), Arpaşul de Jos (1794), the church "De pe groapă” of Sibiu (1802), Arpaşul de Sus (1802), Fofeldea (1804), Sărata (1806), Voievodenii Mici (1809), Viştea de Jos (destroyed, painted in 1810), Colun (1811). See: Ioan Abrudan, "Un ansamblu iconografic inedit: pictura lui Ioan Grigorievici şi a zugravilor familiei Grecu, din biserica satului Cornăţel” in: Revista Teologica, nr. 2/2009, p. 294, note 23.

5 I. Abrudan, "Un ansamblu iconografic inedit: pictura lui Ioan Grigorievici şi a zugravilor familiei Grecu”, p. 295. 
ans throughout the last century. It should be noted that, in a period of time marked by the influence of western styles in the Romanian religious art, the Transylvanian painters still kept a constant link with the tradition of the Eastern iconography. The devotion shown by the painters in southern Transylvania for the values inherited from the Byzantine culture and spirituality came to be appreciated far beyond the Carpathian mountain chain. In Oltenia, for example, on several occasions, such Transylvanian painters were requested by some founders (the so-called "ctitori") who didn't uphold with the new Westernized trend, promoted by the local craftsmen.

\section{Church painting in Transylvania: from the illustrated Bible to the message of a national character}

In exchange for the Union with the Church of Rome, the Romanians demanded rights and freedom, including their access to higher forms of education, which, finally, led to the development of the so-called "Şcoala Ardeleană" (Transylvanian School) at the end of the $18^{\text {th }}$ century as a socio-political movement affiliated to the Enlightenment style with the political support of the Habsburg Emperor Joseph II. The formation of an indigenous intelligentsia assured the superiority of the Greek-Catholic propaganda through written and printed word, while the Orthodox could barely remake their communities under the leadership of the Serbian bishops. Accordingly, the anti-unionist message had to be sent by a different way, particular to the Orthodox rite: church painting. It is well known that the Uniatism, although it was an iconoclast phenomenon per se, chose to distinguish itself from the Greek-Oriental worship by covering the frescoes or painting the walls of the newly built churches blue with golden stars. On the contrary, the painting of the new Orthodox churches, built after 1780, became very dense, containing a rich graphical material following the themes and the layout of scenes in the manner they were brought into Transylvania. The schools of painters trained in the art centres of Brancovan inspiration emerged in southern Transylvania, in Răşinari, Braşov, Feisa, Alba Iulia and Orăştie.

As the verbal and written=propaganda was dominated by the Greek Catholics who had access to higher education with the help of the Habsburgs - supporters of the Roman Catholic Church and the Uniatism - the Orthodox opted for a visual message as a means of countering them and asserting the political and religious vision specific to those times. Evidence of the very intimate link that interrelated the political ideology and the doctrine can be found in the works of Pop Ionaşcu Zugravul (Avrig - 1762, Monastery from Sâmbăta de Sus - 1766 and the two churches in the village Sâmbăta de Sus), Pantelimon Zugravu (Sâmbăta de Jos - 1806 and Voievodenii Mari -1812), 
Teodor Zugravul (Veneţia de Jos - about 1801), Sava Zugravul (Calbor 1813), but the most expressive and representative paintings for the ethos of that era remain the frescoes signed by the Grecu family's members.

The political changes in the $17^{\text {th }}-18^{\text {th }}$ centuries led to a series of mutations in the consciousness of the inhabiting nations who found their expression through historical texts, documents, regulations or art. The same phenomenon was manifested by a certain delay in the development of Romanian folk art, which presented, at the beginning of the $19^{\text {th }}$ century, signs of renewal and an enrichment of the senses.

"We are now witnessing the crystallization of a new vision of the world and life and the mutations occurring in the way of thinking will influence the iconographic representations through the emergence and the noticeable continuity of some elements of narrative character, with reference to the reality of the era, historical events, technics, the style and the iconography being closely linked. The change of the mentality and the evident presence of some laic elements in the artistic expression and in the post-Byzantine ambience are reflected in the painters' attitudes regarding their own works, to which they give other purposes than the intended ones, linked to their desire to have their own say towards the history of their people through emotional participation in the historical events, reflecting themselves, even allusively, through the intercession of religious images"6.

\section{The Grecu family and the cataloging of their work}

Unfortunately, we do not have much data on this family of painters who gave three generations of church painters: Alexandru, Gheorghe, Nicolae, Nicolae's son - Nicolae, Gheorghe and Vasile Grecu. The family came from the village Arpaşu de Jos, but many of its members lived in Săsăuş (com. Chirpăr, Sibiu county), glimpses of their biography being offered especially by the inscriptions of the churches painted by them. These inscriptions help us restore, to some extent, the route they followed. What interests us particularly is the fact that, despite their supposed apprenticeship along with painters trained in the Brancovan School, these painters are considered creators of folk art who enrich the décor through visual elements that have an obvious moralizing role.

The political easing by the emperor Joseph II allowed, therefore, the resumption of construction of the Orthodox churches and the celebration of a century since the Romanian Church's schism - and 60 years from the begin-

6 Maria Zintz, Pictura murala a bisericilor româneşti din Ţara Făgăraşului în secolul al XVIIIlea şi în prima jumătate a secolului al XIX-lea, Bucureşti 2011, p 202. 
ning of the struggle for the defence of Orthodoxy, respectively - favoured the clarification of the place the Orthodox Romanians had within the Transylvanian society. Being resigned to the status of a tolerated nation, the Romanians chose to identify their own destiny with the one of the martyrs and even of the Savior, a theme that would, artistically, dominate the artistic creations by the Grecu family. Interestingly, these ideas have evolved in time and were more strongly promoted only by some members of this dynasty of painters who through their naive but cautionary style and with the express intention to include images that aren't recorded in the Byzantine Erminia - brought into the context of the biblical narration a very important and personal contribution to the understanding of that historical time. Thus, the biblical scenes, especially the Passion theme, have borrowed something from the appearance of the Romanian history and it remains worthy of "their attempt to create more natural and fuller scenes with a dynamic narration where dialogue seems natural even if, through the expression of some truthful feelings and emotions, they diverged from the canons established in the Erminia, whether it regards landscapes with landforms and natural vegetation, or indoor images"'.

Concerning the first two generations, a short inventory of the churches painted by them could be made. Therefore, some of the inscriptions mention them directly, while others have been assigned by specialists who took into consideration the painting technic, the composition style and features that are common to these churches grouped in the Făgăraş Country and on the Hârtibaciu Valley as it can be seen from the map below.

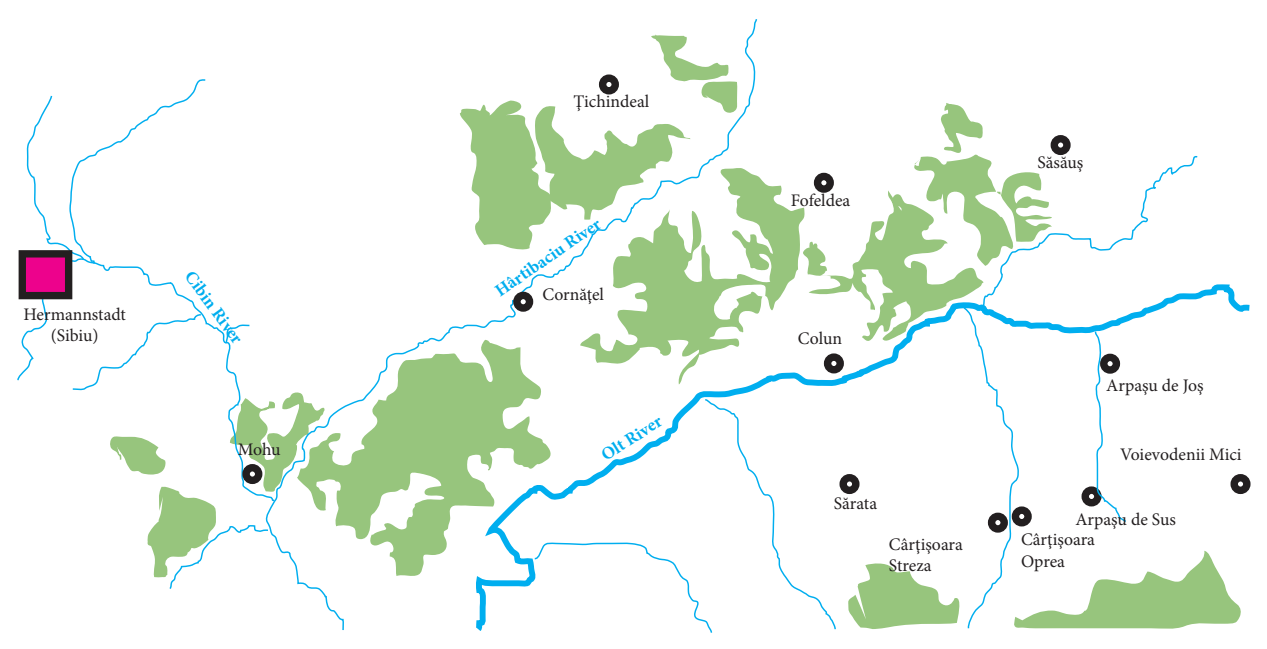

Ibidem, p. 209. 
Chronologically speaking, these churches were painted as follows:

\begin{tabular}{|c|c|c|c|c|}
\hline & Village & $\begin{array}{l}\text { Date of } \\
\text { building's } \\
\text { construction }\end{array}$ & $\begin{array}{l}\text { Date of } \\
\text { painting's } \\
\text { execution }\end{array}$ & Authors \\
\hline 1 & Săsăuş & 1780 & before 1804 & $\begin{array}{l}\text { probable Nicolae and } \\
\text { Alexandru }\end{array}$ \\
\hline 2 & Mohu & $1782-1785$ & 1804 & $\begin{array}{l}\text { Nicolae and } \\
\text { Alexandru }\end{array}$ \\
\hline 3 & Sărata & 1796 & 1806 & unsigned \\
\hline 4 & Cârţişoara Oprea & 1806 & 1809 & unsigned \\
\hline 5 & Arpaşu de Jos & 1790 & 1810 & $\begin{array}{l}\text { Nicolae and his son } \\
\text { Nicolae }\end{array}$ \\
\hline 6 & Arpaşu de Sus & $1798-1815$ & 1815 & Nicolae \\
\hline 7 & Ţichindeal & 1791 & 1818 & unsigned \\
\hline 8 & Colun & cca $1808-1811$ & after 1818 & unsigned \\
\hline 9 & Cornăţel & cca 1792 & 1820 & unsigned \\
\hline 10 & Voievodenii Mici & 1809 & 1821 & $\begin{array}{l}\text { Nicolae and } \\
\text { Gheorghe }\end{array}$ \\
\hline 11 & Fofeldea & $1808-1810$ & 1821 & $\begin{array}{l}\text { Nicolae and } \\
\text { Gheorghe }\end{array}$ \\
\hline 12 & Cârţişoara Streza & 1818 & 1824 & Nicolae the son \\
\hline
\end{tabular}

The iconographic cycle of the Lord's Passion is usually carried out in twelve episodes even though, compositionally, each scene was designed as a rectangular single image, framed by borders of various colours. Identifying each moment is facilitated by the Cyrillic inscriptions accompanying the images. Of all these scenes, relevant to this essay are those describing the events from the Savior's arrest in the Garden of Gethsemane until His crucifixion.

Among the compositions performed by the Grecu family our attention is drawn to the frescoes from Sarata (1806), Tichindeal (1818), Colun (after 1818), Cornăţel (1820) and Fofeldea (1821), the first four being unsigned, but the manner of expression and the composition style indicate that it was made by Nicolae Grecu with his brothers.

It should be noted that, even though they follow this traditional iconographic plan with Brancovan influences transmitted through the painting 
"schools" in Transylvania, the works of the Grecu brothers are imbued with the Baroque spirit, but in a folk manner, which gives their frescoes the features of the naive paintings. Since the 18th century a general feature of the painting can be seen. This is applied to both frescoes and icon collections in Transylvania: the pleasure to describe the biblical stories, which the artists have interpreted in fully new compositions, where the main action of the scene is often consumed by the multitude of the adjacent episodes, taken from daily life ${ }^{8}$.

\section{The scenes' description}

The recurring theme of the Passion cycle's frescoes is the identification of the Passion of Jesus Christ and His sufferings with the difficult fate of the Romanian people, disadvantaged and subjected for centuries to humiliations that come to represent a "cross" on which the resigned Romanian peasants crucify themselves in the absence of a real alternative. In the paintings from Săsăuş (before 1804) and Mohu (1804) the painters have followed quite accurately the indicated Byzantine Erminia as it was established over time and was recorded by Dionysius of Furna in the first half of the $18^{\text {th }}$ century. Starting the painting from Sarata (1806), the Grecu brothers introduced a number of elements designed to customize the characters of the biblical scenes and they established a clear difference between the characters' ethnicity, depending on the role they held in real life and in the Scripture's narration, respectively. Thus, the ethnic nations in Transylvania come to be individualized: Saxons, Hungarians, Austrians and Romanians, all with a precise role in the representation of Christ's Passion.

Thus, the soldiers who accompany Christ from the Garden of Gethsemane until His crucifixion on Golgotha, become exponents of the brutal force represented by the Habsburg imperial army and the painters assigned them specific items to be identified as such. Therefore, the scene entitled Cand au sărutat Iuda pe Iisus şi l-au prins în grădina Ghetzmani (When Judas kissed Jesus and they caught Him in the Gethsemane Garden) we are dealing with a group of soldiers, conventionally represented, holding swords and lances, wearing metal helmets on their heads (Tiichindeal -1818) or Turkish turbans (Cornăţel - 1820; Fofeldea - 1821), except their captain, dressed according to the Habsburg military officers' uniforms. Also, unlike the frescoes painted in Mohu, Arpaşu de Jos, Cârţişoara Streza or Cârţişoara Oprea, the physical features of these soldiers are complemented by particularly prominent

\footnotetext{
8 Marius Porumb, "Răşinari, un centru de pictură din secolul al XVIII-lea”, in: Anuarul Institutului de Istorie şi Arheologie Cluj-Napoca (1983-1984), p. 388.
} 
Dragoş Boicu

moustaches specific to the Austrian Hungarian hussars, even if the soldiers are dressed in medieval attire?

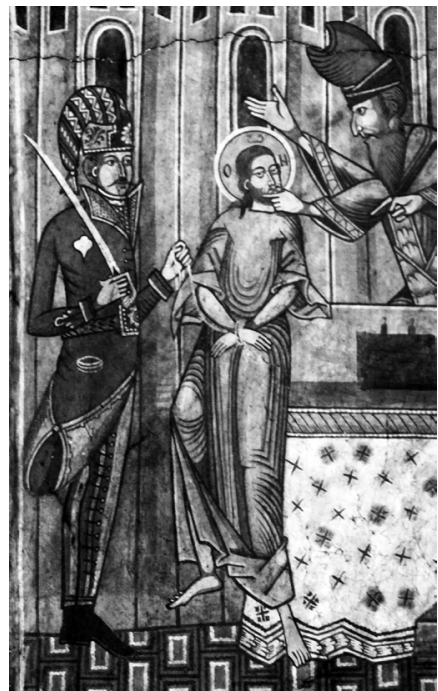

Christ before Annas Grenadier uniform

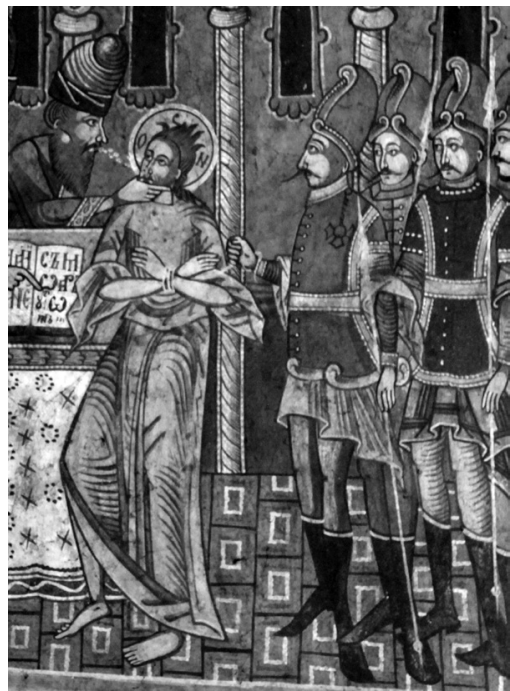

Colun

Christ before Caiaphas Heavy cavalry uniform

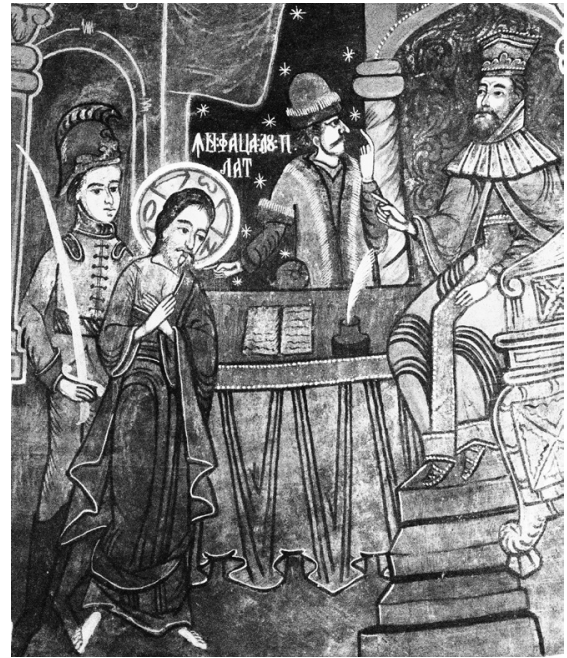

Voievodenii Mici

Christ before Pilate

Austrian officer

9 M. Zintz, Pictura murala, p. 197. 
During the Passion the Habsburg soldiers become more numerous representing both "German" regiments (including Walloons, Moravians, Croatians and Italians) and "Hungarian" light cavalry units. The latter were composed mainly of Hussars whose uniform is easily distinguished in the frescos from Colun and Fofeldea. An officer or a soldier with grenadier uniform is often remarked (Sarata Colun and Ţichindeal), infantry (Sarata Colun and Ţichindeal) or cavalry (Colun).

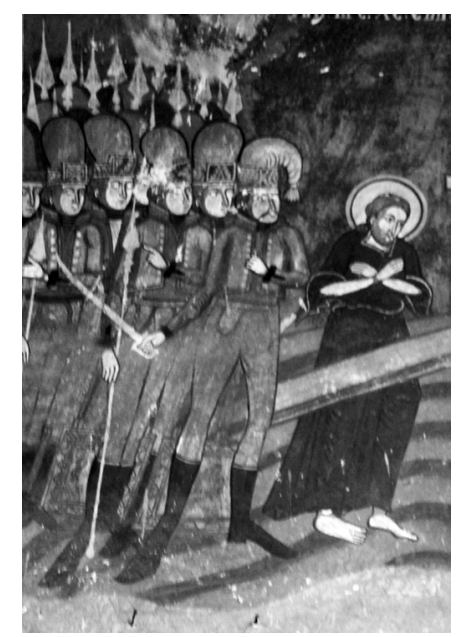

Colun

Christ on his way to Golgotha

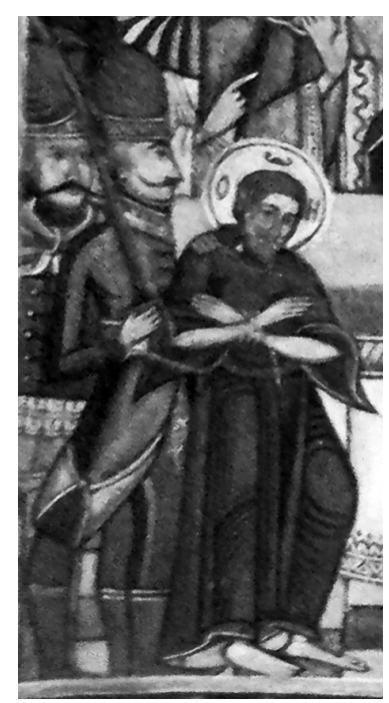

Christ before the judges

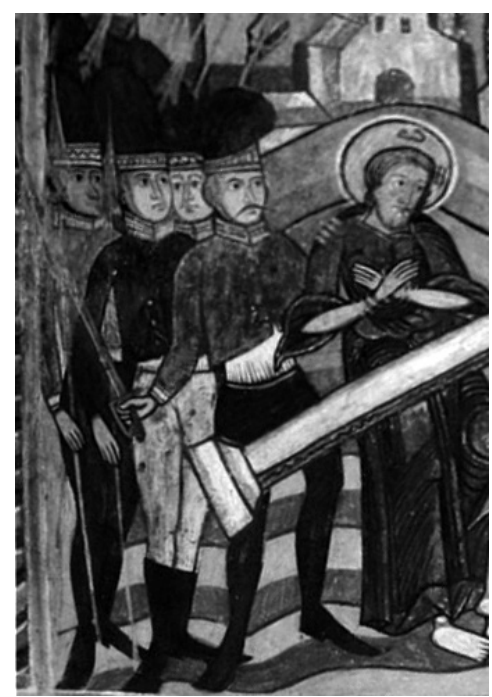

Fofeldea

Christ on his way to Golgota 
The groups of soldiers are quite well individualized and it is quite interesting that the characters are treated with considerable attention, focusing on details. Thus, uniforms abound of buttoned-bumps, chenille, gallons, aiguillettes and the varied designs of helmets, even if sometimes only stylized, always find their correspondents in the military outfits of the era. Comparing the representations from the churches painted by the Grecu brothers with the contemporary lithographs and drawings of the uniforms, we notice a greater sense for details and the fidelity to historical reality insofar as it is taken into account in an Orthodox icon. Unlike the Western painting which abounds with details and elements from the authors' contemporary material life, according to the Byzantine Erminia, the objects or clothing serve as symbols and allusions to the doctrine emphasizing, thus, the idea of transfiguration specific to the Eastern hieratism.
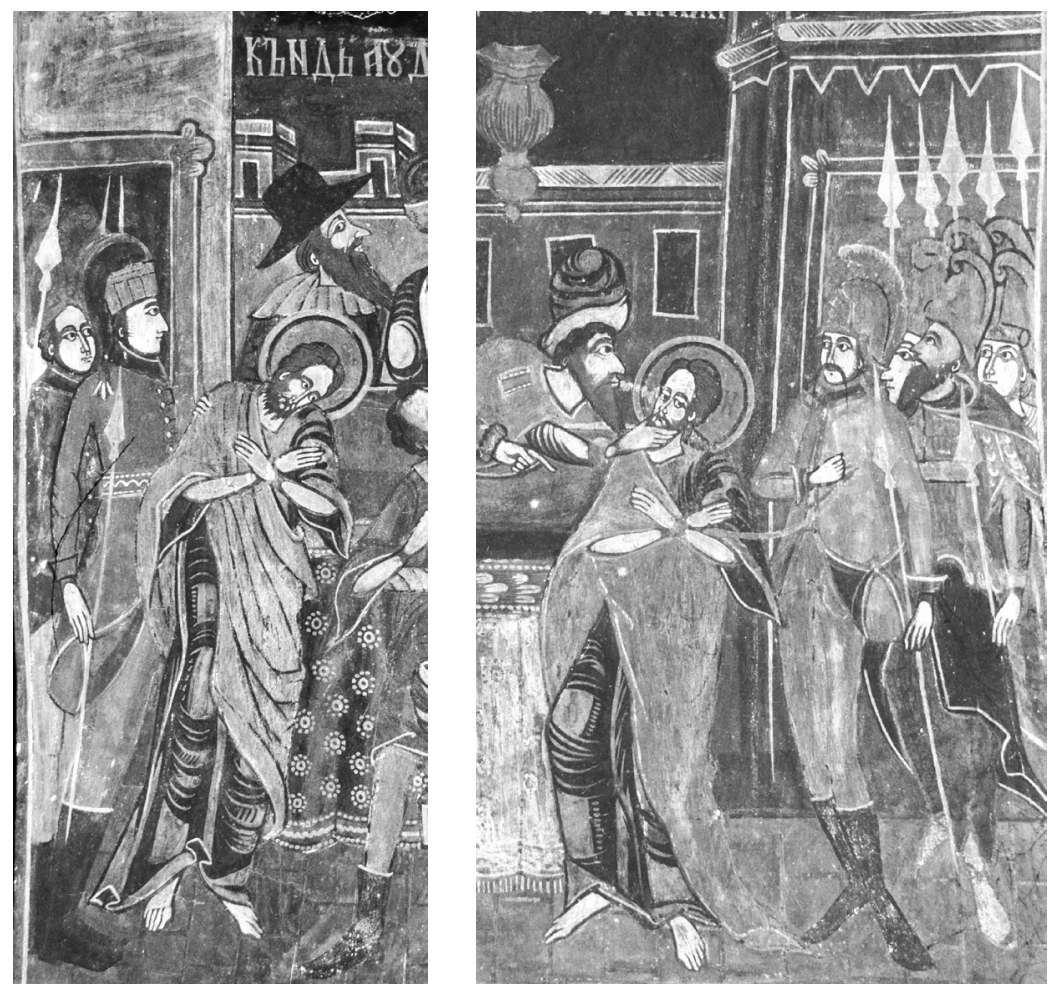

Tichindeal

\section{Christ before Annas Christ before Caiaphas}

The only anachronistic element remains the weaponry: either a traditional spear or a sword occasionally making place for an officer sword typical to the $18^{\text {th }}$ and $19^{\text {th }}$ centuries. 
The Ethnic Pluralism of the Nineteenth Century in Transylvania
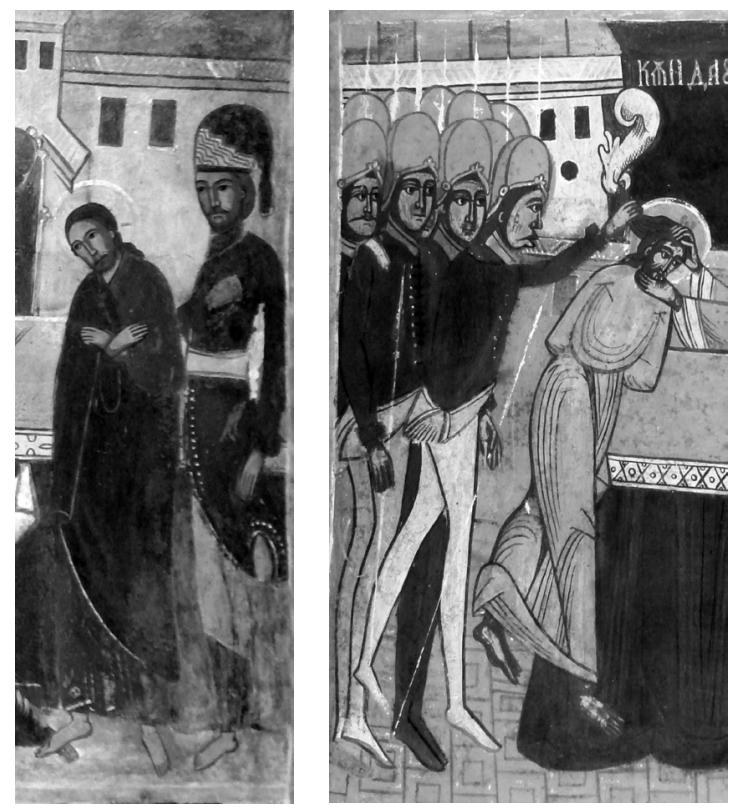

Christ before Pilate

Sărata
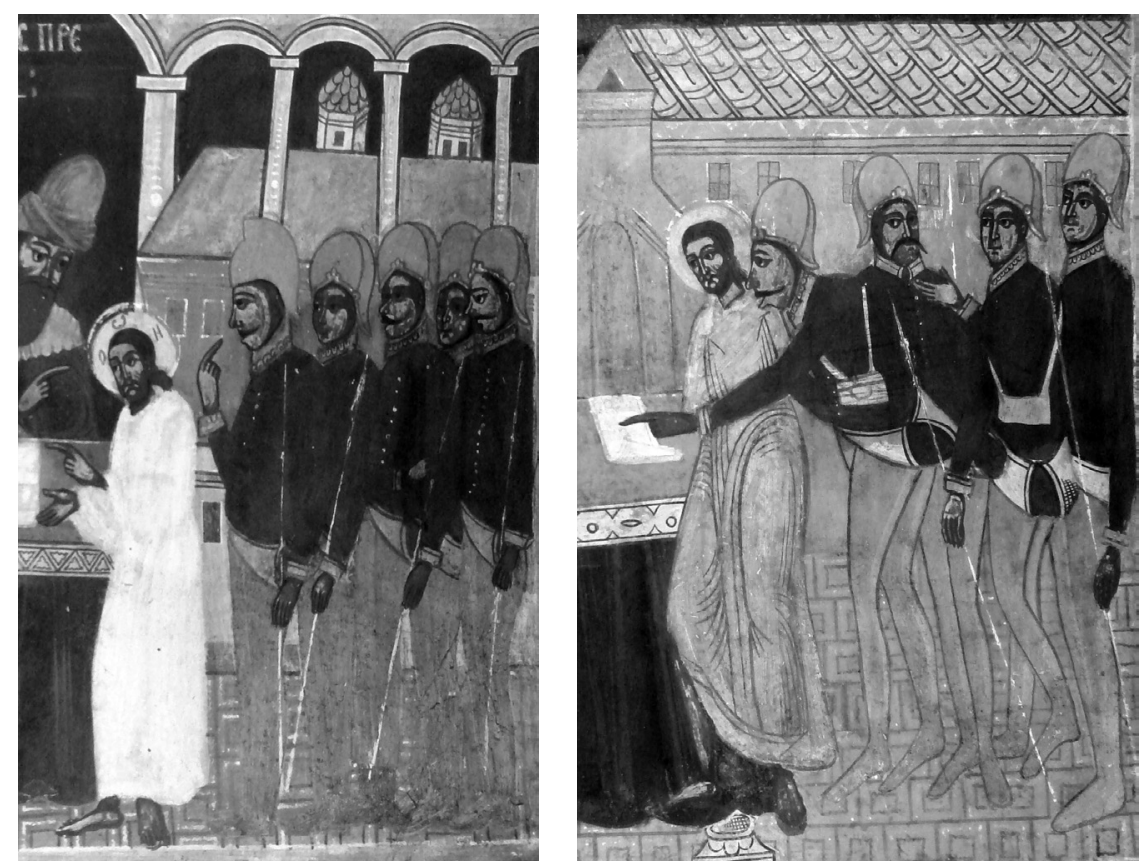

Sărata

Christ before Herod

Christ before Caiaphas 
The firearms are missing in all these cases, except the scene Când l-au dus pre Hristos să-l răstignească (When they took Christ to crucify Him) from Fofeldea. In this case, the convoy that goes to Calvary (Christ the Savior, Simon of Cyrene and the escort guard composed of Hussars) is preceded by a janissary endowed with all his specific equipment. The association of the Austrian domination with the Turkish one indicates the position of the oppressor exercised by the "neamţ" (a synonym for German, Saxon, meaning also "foreigner") or "alien" over the Romanian people portrayed as Simon of Cyrene, represented in typical Romanian clothes.

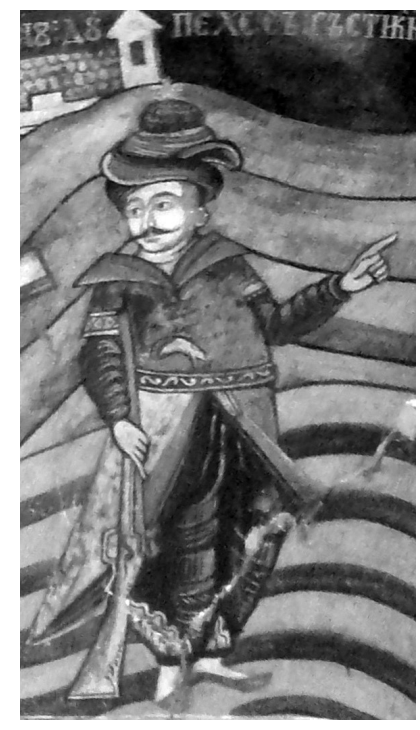

Fofeldea

Janissary

The Saxons, brought as colonists into Transylvania in the middle of $11^{\text {th }}$ century, acquired over time, more and more rights and the territorial-administrative, judicial and religious autonomy were consistently stipulated by the kings of Hungary. In the $15^{\text {th }}$ century, together with the Hungarian nobility of Transylvania, the Saxons were members of Unio Fraterna, best known as Unio Trium Nationum founded in 16 September 1437 during the Uprising from Bobâlna led by Antal Nagy Budai. By this agreement, the three nations have pledged mutual support against the exterior dangers (the Ottoman expansion) and the interior ones (peasant revolts), which led to the tacit exclusion of Romanians, Jews, Greeks and Armenians from the political life of Transylvania. 
The Battle of Mohács in 1526 led to the abolition of the Hungarian kingdom that was divided into three: the west was annexed by Austria, Transylvania became princedom - independent from Hungary, under the Ottoman suzerainty; and, central Hungary became Pashalic under the Ottoman Empire's dominion for over 150 years, during the $16^{\text {th }}-17^{\text {th }}$ centuries. Under these circumstances, the privileged class status of the Saxons became more prominent, holding administrative positions in the micro-regions inhabited by them, as Altland (the region between Olt and Hârtibaciu) or Waldland (the region between Hârtibaciu and Târnava Mare), where there are churches painted by the Grecu brothers.

Therefore, it is no wonder that the Saxon patriciate plays a dominant authority role in the scenes that adorn the churches from Fofeldea and Tichindeal. Thus, in the phases of Jesus's trial, the high priest Caiaphas and his father in law, Annas, as the Pharisees and the crowd waiting outside Pilate's palace are dressed as the Saxon patricians. Perhaps the most striking example is the fresco from Tiichindeal where Annas is represented as an old man with a long beard, wearing a dolman (a long Turkish robe open in front) decorated with buttons and chenille, girded waist and covered by a cloak with fur edges. The same type of clothing is reserved to Caiaphas, too. From the conventional representation, only the miter on his head is preserved, painted like a high hood split in two, as recalled in Dionysius of Furna's ${ }^{10}$ Byzantine Erminia. In the fresco from Fofeldea the Jewish crowd is dressed in similar style, wearing a short cloak, whose folds seem to indicate even a folded collar (ruff; German: Halskrause), specific to the Protestant clergy.

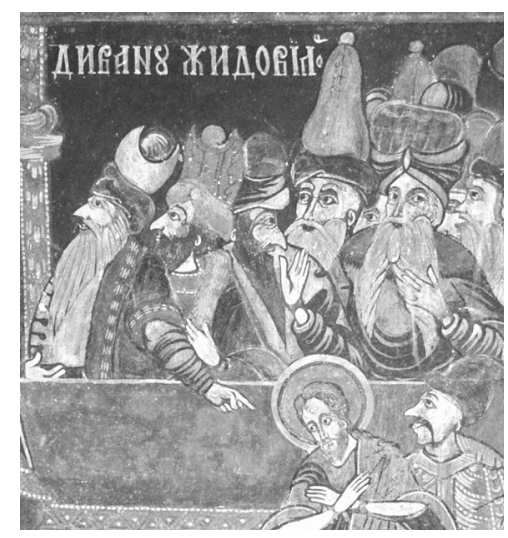

Ţichindeal

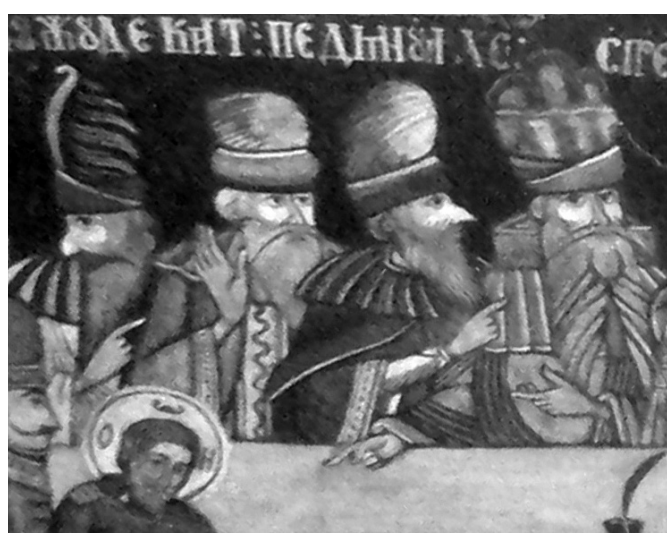

Fofeldea

Christ before the judges

10 Dionisie din Furna, Erminia picturii bizantine, Bucureşti 2000, p. 114. 


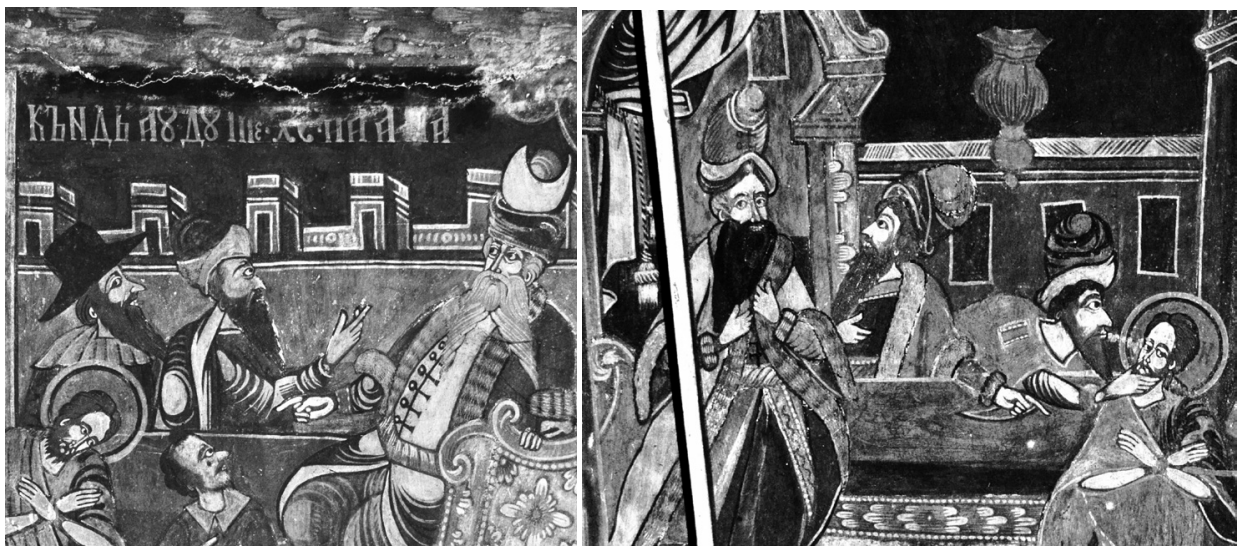

Christ before Annas

Ţichindeal

Christ before Caiaphas

Similarly to the soldiers, the clothes represented in the frescoes have a correspondent in the contemporary reality. The Saxon garb of the patricians had already in the $16^{\text {th }}$ century borrowed features from the clothing of the Hungarian and Polish nobility, actually derived from the oriental garb of the higher Ottoman social stratum. Thus, very early clothes with oriental influences were imposed among the Saxon male patrician garments - dolman and mantle - and the portraits of the senators in Brassov, at the end of the $17^{\text {th }}$ century, show the old clothing representative for the Saxon patricians as it was passed over centuries: the long baize dolman, decorated in the chest area with bump-buttons and golden band, stitched with drawstring gold and tied at the waist with a cord of red silk, masterfully knotted, to which is added the long cloak like a cape; on its hem was sewn a strip of fur and on the shoulders could be seen the so-called felsö (Hungarian), a cape lined with fur ${ }^{11}$ (see the portraits of Simon Drauth patrician father and son, or that of Martinus Closius).

Regarding the characters' physiognomy, "Jesus's judges" are portrayed with ugly figures and tough expressions, indicative of the decisions that they would take, and their oversize is intentional and not due to the painter's clumsiness, who manifests obvious feelings against them" ${ }^{12}$.

Although the Hungarians appear timidly along with Austrian groups of soldiers from the scene of catching and escorting the Saviour before Annas and Caiaphas, they become the protagonists of two distinct scenes in which Christ is beaten and mocked before crucifixion (Cornăţel, Colun, Ţichindeal).

11 Radu Popica (ed.), Portretele Patriciatului Săsesc din Braşov. Un capitol de artă transilvană, Braşov 2013, p. 48-49

12 M. Zintz, Pictura murala, p. 205. 
Dressed in tight clothes, a sign of evil ${ }^{13}$, and covered with hats or Phrygian bonnets, the torturers distinguish themselves by their outfits, their short jackets, tight pants and boots reminding us of the Hungarian townsfolk of the time. In the first scene Christ, tied to a stone column, is scourged by two people, while in the mockery scene, other three torturers torment Him by fixing with pliers a crown of thorns on his head and hitting the crown with a hammer.

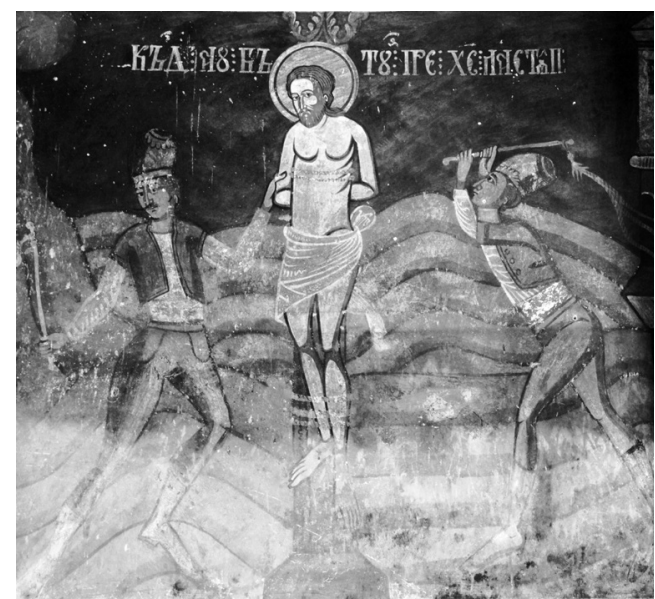

Colun

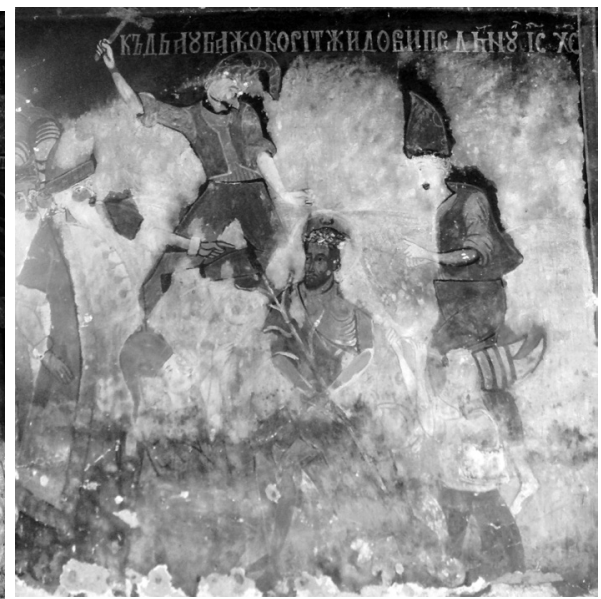

T3ichindeal

Christ scourged

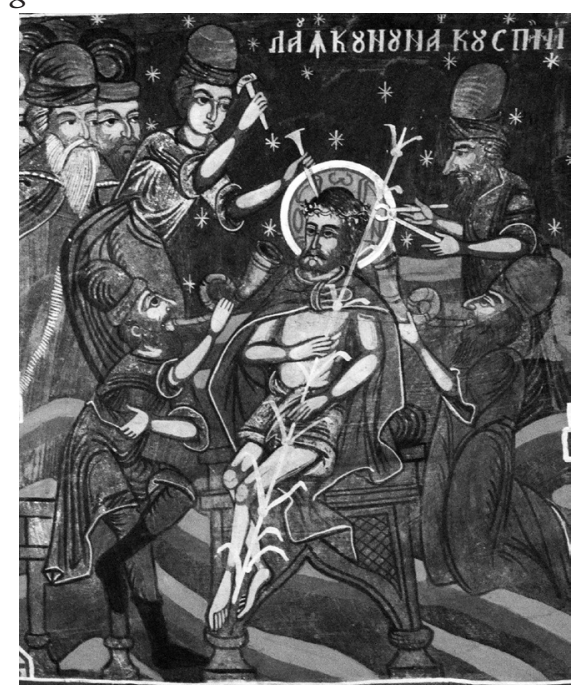

Voievodenii Mici

Christ crowned with thorns

13 Anca Niţoi, "Imaginea celuilalt - imaginea necreştinului. Evrei şi musulmani în pictura altarelor poliptice transilvănene - secolele XV-XVI” in: Studia Universitatis Cibiniensis. Series Historica, I, Sibiu 2004, p. 317. 
The frescoes reflect also the attitude of these peasant-painters towards "townspeople" whom they didn't trust, representing the fact that the village community was still strong, and the city represented for them a repressive force. Excepting the church from Mohu, in the scenes of the Passion, judges, Pharisees and other characters mocking Jesus are wearing clothing items typical for townspeople's costumes. The variety of hats provides a rather picturesque aspect and originality to these images" ${ }^{14}$.

As expected, the representation of the Romanians is meant to put them into a favourable light as in the scene Când l-au dus pe Hristos să-L răstignească (When they took Christ to crucify Him). On the road to Golgotha Jesus, still dressed in purple garb, falls exhausted under the weight of the cross. A group of soldiers lead him, hitting and threatening him, while another soldier and the Jewish leaders open the way and seem to order Simon of Cyrene, barefoot and dressed in clothes specific to Romanian peasants, to take over the burden of the Saviour's cross on his shoulders. As in real-life, the outfit is simple, consisting of a long shirt, tight pants and a cloth belt over the shirt (Fofeldea, Tichindeal) or a leather girdle (Colun). The purposeful striking similarity between Christ and the image of Simon - the Romanians' exponent - refers to a subtle but insufficiently explored theology of the likeness [Gen 1, 26]. Through their suffering, poverty and humble condition, the Romanians are more like the incarnated Son of God, He Himself a prototype of Adam.

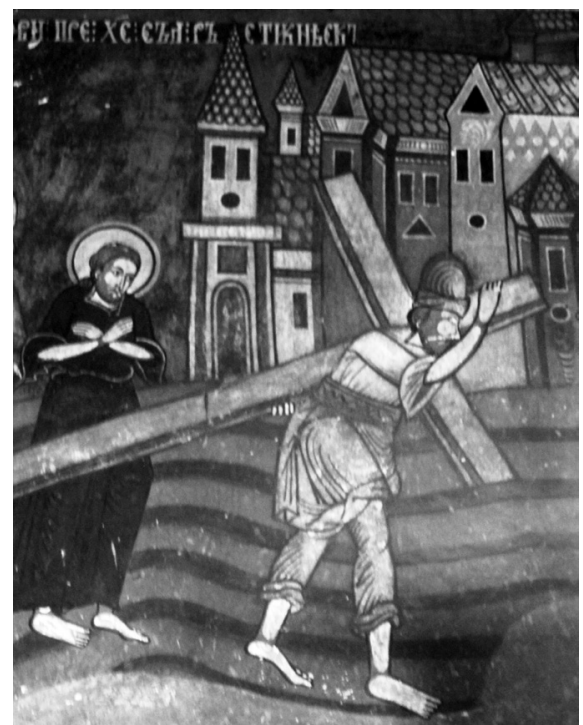

Colun

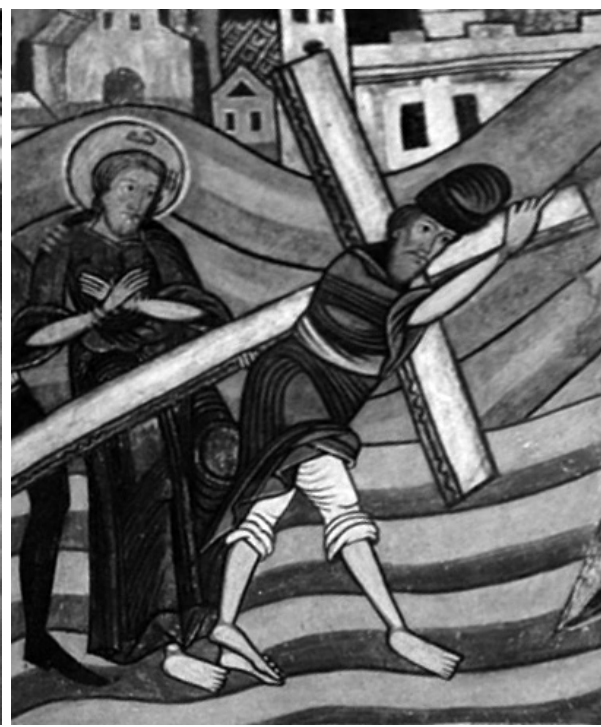

Fofeldea

14 M. Zintz, Pictura murala, p. 209. 


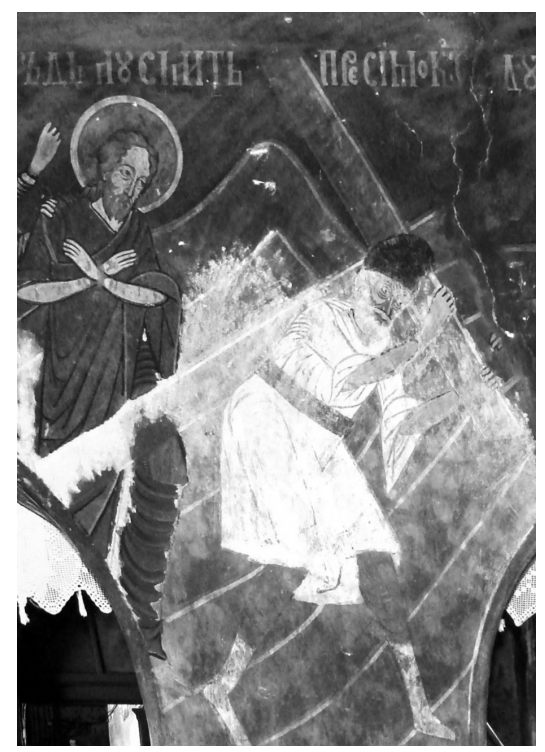

Ţichindeal

Therefore, the representation of the inhabiting nations in Transylvania in the Passion's Cycle serves to underline the disadvantaged status of the Romanian people, oppressed by the privileged nations, who are recreating the dramatic setting in which Christ was crucified. The Habsburg military force, the Saxons' inequitable judgment and the torment inflicted by the Hungarians through their policies have prevented the Romanians from overcoming their disadvantaged status, denying their access to education and trade that would have allowed their emancipation. Their status is highlighted by Simon of Cyrene's clothing, so simple that it can easily pass as an ancient one, and the key element is the absence of footwear: in scenes representing the way to Golgotha the only bare-foot characters are and Simon and Christ. The poverty and the suffering balance the distinction between the two destinies: Simon willingly assumes Christ's cross because he is the only one who can understand His sufferings since he himself lives daily under the oppression and torture coming from the other inhabiting nations.

The representation of the privileged nations as enemies of Christ, fully God and fully man, is a call to trial for those who, oppressing the man, oppress God Himself [Mth 25, 40-45]. The foreigners' demonization contributes to highlighting the antagonism that lies in these images. Although absent in the rest of the scenes from the Passion Cycle, the Romanians are always placed on antithetical positions to the privileged nations, showing their compassion in contrast with the cruelty of the foreigners. 
However, it would be wrong to interpret these images as simple selfpity and self-victimization attempts. The frescoes intended to denounce the cruelty of the inhabiting nations and foretell the damnation of those who tormented, mocked and, finally, crucified Christ. The oppressors' damnation became a recurring theme in church painting in $19^{\text {th }}$ century Transylvania and caused the reaction of the political authorities of the time who found it challenging and, therefore, imposed their covering with lime after the establishment of the Austro-Hungarian Empire in $1867^{15}$.

In parallel, in Transylvania, another branch of folk art developed icons painted on glass, imbued with the same identity message. Thus, similar creations put in a negative position the representatives of other nations, such as the well-known icon from Făgăraş, preserved in the Museum of icons on glass Pr. Zosim Oancea - Sibiel, illustrating the parable of the Rich Man and poor Lazarus, where the wealthy man is wearing clothes specific to a Hungarian nobleman (Grof), or the series of the Resurrection icons in which the soldiers guarding the tomb are identified with Austrian or Hungarian army regiments.

The idea of the national oppression of the Romanians can be deciphered in other more subtle scenes as indicated by the research conducted by the art historian Maria Zintz ${ }^{16}$, for instance the scene of the Beheading of John the Baptist.

In the same way, Ioan Fulea explains Christ's mockery scene from Fofeldea where, instead of a crown of thorns, a crown of red-hot iron was placed on his head while other torturers are blowing horns into his ears, imitating a vintage stamp with Gheorghe Doja: "this scene [...] and others like it presents a fine illustration of the troubled past of the Romanians in these parts, and represents a form of struggle against the past oppressions"17. Similarly, Ioan Fulea makes a reference also to the scene of Joseph's detention, imprisoned by Putifar in Egypt: "Joseph in prison with two other characters; behind them there are three windows (which did not exist in Egypt at that time), resembling the windows of the prison in Alba Iulia from a vintage stamp representing Horia, Cloşca and Crişan" ${ }^{18}$. The tone of this parallel is perhaps slightly exaggerated and forced and must be understood in the his-

15 It worth mentioning the case of the Orthodox church from Tulgheş (today part of Săcele), Brasov County, where in 1877 the offending scenes were covered with several layers of lime, which were removed only in 1939.

16 M. Zintz, Pictura murala, p. 198.

17 Ioan Fulea, "Biserici-monumente istorice, pictate de fraţii Grecu" in: Arhiepiscopia Sibiului-pagini de istorie, Sibiu 1981, p. 217.

18 Ibidem, p. 220. 
torical context in which the text was drafted (before the events of 1989) when a certain kind of history subordinated to the political agenda of the Communist Party was encouraged promoting a "persistent Romanian nationalism", with its "ethnicist» and religious side well emphasized (A genuine Romanian is considered to be the Romanian ethnic and preferably Orthodox)"19.

\section{Conclusions}

Despite the development of the iconographic programs, the frescoes painted by the Grecu brothers remember the sets of the large ensembles beyond the Carpathians, in Walachia and Moldova but also other Transylvanian decorations. These frescoes express not only the spirit of the time or the mentality of the community to which they belonged, but they also represent an opportunity to show the painters' originality and personality, their need for personal affirmation and artistic individuality, connected to a new sensitivity of a given historical context. Although it is not possible to talk about an evident expressiveness of the characters, there are still clear attempts to individualize them - even if they involve the detachment from predetermined canons of the painting notebooks or Erminia's models -, especially through accessories: hair, beards, moustaches and garments that make a clear reference to the ethnic difference between the different participants in the capture, trial and murder of Jesus Christ, managing to convey in the iconographic representation a sense of authenticity, temperament and their own personality, whose fame is preserved to this day among the villages on Hârtibaciu Valley and around Făgăraş ${ }^{20}$.

The representation of the inhabiting nations in Transylvania in the Passion's Cycle highlights the disadvantaged status of the Romanian people who were oppressed by the privileged nations: by the Habsburg military force, the inequitable judgement of Saxons and the torments inflicted by Hungarians through their policies. All of these recreate mutatis mutandis the dramatic setting in which Christ was crucified. These monuments of folk art, made by the Grecu brothers, testify to the complex relationships among the inhabiting nations in Transylvania, illustrating how the Romanians perceived the harsh reality of being repeatedly exposed to political, social and religious abuses.

Photo credit: Ștefan Mărculeţ

19 Lucian Boia, Cum s-a românizat România, Bucureşti 2015, p. 8.

20 M. Zintz, Pictura murala, p. 202-203, 210. 